Trivent Publishing

(C) The Authors, 2018

Available online at http:/ / trivent-publishing.eu/

Series: Applied Ethics: From Bioethics to Environmental Ethics

\title{
A New Pro-Natalist Tool: Parenthood as a Form of Public Employment
}

\author{
János I. Tóth
}

University of Szeged, Hungary

\begin{abstract}
Low fertility rates currently represent a serious problem across Europe and East Asia. A possible solution to this crisis is the radical increase of fertility rates. I suggest that we distinguish between classical (3-child) pro-natalist and radical (5-child) pro-natalist policies, because their logic is different. Classical pronatalism tries to harmonize childbearing and employment for the mother, while radical natalism considers bearing 5-6 children as work, as a kind of public employment. In this chapter, I elaborate on a possible radical pro-natalist institution: parenthood as a form of public employment. This institution, complete with classical pro-natalist measures, could best secure the fertility rate of 2.1 by 2030.
\end{abstract}

Keywords: fertility rate; two forms of natalism; full-time parenthood; Eastern Europe. 


\title{
A New Pro-Natalist Tool: Parenthood as a Form of Public Employment
}

\author{
János I. Tóth
}

\section{The demographic situation in Eastern Europe}

Today's rate of fertility, aging, and population decline is a new phenomenon. In over half of the world's countries, the fertility rate does not reach the ratio of 2.1 child/woman, necessary for population replacement, resulting in zero population growth [1]. The question that arises often is whether low fertility rate is good or bad [2]? The question is divisive. The league of experts I belong to consider too low (or too high) fertility rates to be bad because both are unsustainable [3].

Today, the global average fertility rate is 2.5 children per woman [4]. This high fertility rate average covers significant regional differences. According to fertility rate statistics, Africa $(4.7$ children/woman) and Europe (1.6 children/woman) are going through a serious demographical crisis [4]. While Africa suffers from the demographic consequences of a too high fertility ratio, Europe and Eastern Asia (1.6 children/woman) have the opposite problem. Therefore, it is misleading to only concentrate on the global average of fertility rate. In 1949, Sauvy argued that the notion of world population is just a statistical parameter and it is not filled with real content. From a demographic point of view, the world population consists of very different communities. Furthermore, specific demographic problems, be it overpopulation or underpopulation, can only be resolved by the affected population as a nation [5].

The terms "underpopulation," and "depopulation" refer to a problem that affects several countries in the developed world, such as Germany, Italy, Japan $[6,7]$. The phrase "demographic winter" refers to what happens when human populations become unbalanced because the number of the children born is too low. The term "nuclear winter", popularized in the 1980s, alluded to the catastrophic environmental impact of a nuclear war - the long-term consequences of demographic winter could be equally devastating [8]. As Paul 
Demeny wrote:

By the beginning of the twenty-first century, the average total fertility rate was 1.4 in Europe. Such a level, if maintained indefinitely, would result in a population loss of one-third from generation to generation, that is, roughly over each period of some 30 years. Some countries, notably in Southern, Central, and Eastern Europe, period fertility rates were at low levels without historical precedent for large populations [9, p. 306].

Globally, demographic winter is most severely felt in Eastern Europe because low fertility rates in the region are aggravated by high mortality and migration. Latvia used to have a population of 2.6 million in 1990, which shrank to under 2 million by 2014 and is expected to fall below 1.6 million by 2050. If the tendency continues, in 60 years the country is going to lose $40 \%$ of its population [10]. Hungarian society has been suffering from demographic crisis for decades: it is aging and its population is decreasing. Over the past 40 years, the country's population of 10.7 million has decreased by 1 million and the outlook is not encouraging either: without efficient intervention, the population will decrease to 7.9 million by 2060 and will further shrink to a mere 4.5 million of mostly elderly people by 2100 [11-13]. These changes will go hand in hand with diminishment in creativity, productivity, competitiveness, as well as reversed economic growth and decline in GDP, respectively, tax increases. Population decline and aging also entails the economic agony of the society.

The phenomenon justifies the state's vigorous intervention on behalf of a sustainable and stable population, without which no collective good is possible. The Hungarian government intends to resolve the demographic crisis afflicting the country by increasing birth numbers. Since the number of women in childbearing age is given, the only possible solution is to undertake more children, in professional terms, to increase the fertility rate. As Viktor Orbán emphasized

It is important to highlight that the restoration of natural reproduction is a national cause; and it is not just one national cause among many, but the national cause. And it is also a European cause: not just one European cause among many, but the European cause [14].

Furthermore, he also declared that by 2030, Hungary must achieve the fertility rate of 2.1 children per woman, thus formulating a statement, respectively proposing a project that brings the problem of fertility rate to the forefront of politics [14].

What other solutions exist to avoid the demographic winter? There are two alternatives: one of them practical, the other one theoretic. The practical 
alternative is mass migration, the path chosen by Western Europe, while the theoretic solution is some sort of transformation of the human being (e.g. immortality) or of human reproduction (cloning, in vitro reproduction). Socially, as well as morally, both alternatives are much more problematic than striving to increase the fertility rate. Moreover, the traditional populations of Hungary and Eastern Europe are not keen on either mass migration or transhumanist modifications.

Consequently, for Eastern Europe, the best course of action for stabilizing its population is the radical increase in fertility rate. The solution will serve not only the survival of the nations, but will also promote well-being, as people who live in an aging and destabilized society already are and will be even more exposed to a great deal of suffering: rising taxes, decreasing pensions and subpar services. Setting the goal of achieving the fertility rate of 2.1 to ensure the stability of the population might seem to be an innovative and unusual objective, but it is also one that is socially necessary and ethically correct. As I have previously argued, this population policy objective must be set not only by Hungary, but by each country, including African countries. In a nutshell, each country, each political unit - nation, country, state - must strive to achieve replacement-level fertility [3].

The achievement of the objective raises questions about what pro-natalist tools are to be employed by governments. Bureaucratic pro-natalist tools (the ban on abortion and on contraception) violate reproductive freedom and are therefore morally unacceptable. The contradictions and the problems such as prohibitive policy measures can lead to high mortality, the increase in the number of orphans, and more abandoned children. They can be exemplified with Decree no. 770, implemented by the communist regime of Nicolae Ceauşescu as a tool to create a new and large Romanian population by restricting abortion and contraception [15].

Pro-natalist tools based on financial penalties (e.g. the implementation of a tax on childlessness) are also impracticable in democratic societies. Accordingly, only pro-natalist tools developed to reward and to stimulate child bearing can be regarded as realistic and morally acceptable. Hereinafter, I propose to focus exclusively on these types of pro-natalist tools.

\section{The Two Forms of Natalism}

Natalism (or pro-natalism) is the policy or practice of encouraging child bearing, especially by means of government support offered to promote higher birth-rate. Natalism, as a form of public policy, pursues the implementation of social and financial incentives to encourage the population to reproduce. One form of such financial encouragement is tax incentives to reward child bearing and child raising. 
Other types of incentives used are the one-time baby bonus, child benefit provided for a certain period, tax reductions, paid maternity and paternity leave. The system in Sweden allows parents to share 16 months paid leave per child, the costs of the leave being supported in part by the employer and in part by the State. Other European countries, such as Italy, France, Poland, and Germany also offer incentives that combine monthly payments and bonuses. These measures are called classical or 3-child natalist measures. In what follows, I propose to point out that there is another possible form of natalist measures that can be called radical or multi-child natalism.

From a purely logical perspective, there are two ways to improve social statistical parameters: small changes undertaken by many or substantial changes undertaken by few. The same goes for fertility rate: either all fertile people undertake one more child or a few people undertake a significantly higher number of children. The first way is typical of classical pro-natalist family policies, while the second is the method proposed by radical natalist policy. The solution promoted by classical pro-natalist policies has yet to prove its efficiency, since the notion of "everyone should undertake one more baby" is not something that can be achieved by implementing economic incentives and it is impossible to enforce by means of bureaucratic measures either. Evidently, this form of pro-natalist family policy is also necessary, but the result, at best, is only that a few are going to have one more child. As these measures are far from being sufficiently efficient for Eastern Europe right now, radical pro-natalist policy measures are necessary.

I would like to point out that these two basically different pro-natalist family policies should not be confronted - they should rather treated as complementary tools that support one another mutually and are both employed to achieve the common goal: the 2.1 fertility rate.

Let us also examine the problem of low fertility from the perspective of content. In recent decades, in modern industrial economies, the participation of women in the formal work force expanded rapidly. This tendency, reflecting market forces and encouraged by government policy, is likely to continue. Many experts emphasize the double burden on women among the explanatory factors of low fertility, which includes child rearing and work outside the home. As higher birth numbers are socially desirable, the resulting policy task is to implement measures to make maternity and employment more compatible. The higher fertility in the European countries (particularly in Scandinavia) where such measures are heavily applied, compared with those countries (especially in Southern Europe) where they are largely absent, suggests that promoting compatibility (flexible working hours, liberal sick leave, through day care services and the like) are effective pro-natalist policies [9, p. 308]. As Demeny writes: 
But it is far from clear whether the fertility differential so generated is high enough to bring the total fertility rate back to replacement level. Steady labour force participation of women during the childbearing years can certainly be compatible with having one child or even two. It is likely to be far less compatible with sustaining, or even increasing, the proportion of women who have more than two children. Many career-oriented women voluntarily remain childless; many others prefer a single child. It follows that, to achieve average replacement-level fertility, the proportions of such women need to be counterbalanced by high enough proportions of women who have chosen third-, fourthor even higher-order births. There is little indication at present that policies directed at enhanced compatibility achieve that result [9, p. 308].

In other words: the currently existing classical natalist measures encourage working women to undertake 2-3 children. As Demeny also indicated, in many regions, classical natalist measures are no longer sufficient. The reason for this is that the proportion of childless women and women who have a single child is too high. The proportion of childless women in Eastern Europe varies between 10 and 20\% and their number is growing. The results of Miettinen's paper show that childlessness has increased in the age groups of 30-34 and 40-44 years among both men and women throughout Europe, with few exceptions. For example, female childlessness in the group aged 40-44 remains low (below or at 10\%) in Hungary, Poland, Romania, moderate (11-15\%) in France, Germany, the Slovak Republic and high (around 20\%) in Austria, Italy, the Netherlands [16].

According to the data of the Hungarian Statistical Office (KSH), the proportion of childless women in Hungary in the 30-34, 35-39, 40-44 and 4549 age groups in 2011 was as follows: $31 \% ; 12 \% ; 6 \%$ and $5 \%$ respectively. The degree of childlessness reaches the most dramatic levels in the 30-34 age group. Statistical figures improve for the higher age groups, but they are unlikely to return to the low value of the age group past fertile age. The findings of the Hungarian Statistical Office are consistent with the conclusion of Finnish researchers that the proportion of childless women is on the rise [17].

At this point, I propose to examine the group of 35-39-year-old women based on the number of the children they have: 0 children - 12\%; 1 child $19 \%$; 2 children - 22\%; 3 children - 8\%; 4 children - 2\%; 5 children - $0.5 \% ; 6$ children $-0.5 \% ; 7$ children $-0.02 \%$. These figures illustrate that over $30 \%$ of the women in the examined age bracket have 0 or 1 child, while the ratio of the women who have 3-4 children is only $10 \%$ and only $1 \%$ of the women in 
the examined category have 5 to 7 children [17]. The proportion of women who have 0-1 child and their children pull the average downwards, while the women who have 3-6 children and their children pull the average upwards. Since the deficit in the number of children in the first category is significantly more substantial than the number of children on the other side, classical natalist policy measures can no longer be relied on to ensure the desired 2.1 children per woman ratio.

My thesis is as follows: classical (3-child) natalist policies can no longer achieve the fertility rate of 2.1 necessary for maintaining population stability in Eastern Europe. This statement is backed up by the rules of thumb of average calculation.

Let us now examine the transformations required in the above figures to achieve replacement-level fertility. For the sake of illustration, I propose not to refer to those who have 4 or more children and to round the fertility rate to be achieved to 2.0 children/woman - the two approximations more or less compensate each other. In this scenario, the number of women who have 3 children is equal with the number of those having one child, respectively twice the percentage of childless woman. Here I would also like to point out that half as many women with 6 children are needed as there are childless women. The rapport is illustrated in the following calculation:

1 child/woman +3 children/woman $=4 / 2=2$ children $/$ woman.

0 child $/$ woman $+2 \times 3$ children $/$ woman $=6 / 3=2$ children $/$ woman

$2 \times 0$ child $/$ woman +6 children $/$ woman $=6 / 3=2$ children $/$ woman.

Taking the example of Hungary, the ideal proportion of women who have 3 children is $43 \%(=2 \times 12 \%+19 \%)$, compared to the present figure of $8 \%$ in the group. An increase of this magnitude would be impossible to achieve by means of classical natalist measures, even if we assume that the increase in the number of women who have 3 children goes hand in hand with the decrease in the ratio of women who are childless or have a single child.

However, government initiatives to implement a radical natalist policy to encourage child bearing would be viable. As an outcome of these initiatives, the number of women with 3 children would narrowly balance the number of those who have just one child, while the number of women with 6 children would amply balance out the number of childless women. The fertility rate of 2 can be ensured if the number of women with 3 children in the full fertile age bracket (aged between 15-45) increases to $15 \%$ and the number of women with 6 children should reach $10 \%$, this solution being more viable than increasing the number of women who have 3 children to $40 \%$.

Consequently, the ideal, 2.1 fertility rate can be ensured only with a dramatic increase in the number of the women who undertake many (3-4) and very many (5-6) children. This also means that the classical (3-child) natalist 
policies also need to continue. With good reason, classical natalist measures rely on the hypothesis that 3 , even 4 children can be raised by parents who are employed full-time, provided that the state offers comprehensive support to these families and society becomes more family-friendly (adopting a more positive attitude towards large families and household chores becoming more equitably shared by members of the family). However, raising 5-6 children becomes impossible with both parents working full-time. Consequently, such very large families need a completely new support system: the system of radical natalism. This raises a further question: what actual form should this type of support system take? As the principal objective proposed by classical natalism is to harmonize childbearing and employment for the mother, radical natalism, logically, needs to be elaborated on an entirely different foundation. The only way to create that foundation is to make society accept the rearing of very many children as a form of employment. To illustrate the principle with a formula:

Classical natalism: raising 2-3 children + employment

Radical natalism: raising 5-6 children $=$ employment

\section{Full-time Parenthood}

The only way having a very large number of children can be encouraged is by getting society to accept this activity as a form of work that deserves payment. Let us call this type of reproductive activity full-time parental work. What I propose is that the state should elaborate a new form of public employment for parents raising a high number of children of their own $(\geq 5)$ to provide the parents employed in this framework a wage calculated in proportion with the number of the children raised and paid for the parent's lifetime. The position should be available to young married couples or to married couples who already have children. The salary would be initially provided to the mother and it would be calculated in proportion with the number of the children reared and granted for the parent's lifetime. This salary would compensate for the high costs of child rearing and it would also ensure the time, the status and the necessary income for the activity [18].

A full-time mother who rears a large number of children apparently performs the same activities today as the mothers rearing the same number of children used to carry out in the past, but the status of the modern full-time mother is different. On the one hand, the implementation of the institution of full-time parenthood would allow women to choose between work and homemaking. At present, women in Eastern European countries do not have this choice as the two-breadwinner family model forces them to work, that is, they are not allowed to be home-makers or they can stay at home as family caregivers only as low-status unemployed. Interestingly, for example, in the USA, 
wives have the freedom to choose between work and the status of being a homemaker. On the other hand, the proposed position is an option chosen freely, while in the past the role of the homemaker was traditionally imposed on women. Thirdly, the solution I propose would provide the woman payment for her work as a homemaker, which ensures her equal financial participation in the marriage.

Neither Hungarian, nor English language has the perfect term for this new job type. The proposed term, "parenthood as a form of public employment" implies only that the parent receives a wage-type remuneration in return for raising the children. My suggestion, however, would be that such parents receive life-long payments, even after the upbringing of the children is complete.

The concept of full-time parenthood raises numerous further questions in what follows I propose to briefly discuss the most important issues.

\section{How many children is a full-time parent required to raise?}

The government budget would evidently encourage full-time parents to undertake the highest possible number of children, but the childbearing capacity of women is limited. These are the two aspects that need to be reconciled. I would like to point out that the greater the number of children required to obtain the status of full-time parent, the easier it becomes to adjust the institution to the present social structure. If families with two children could also qualify for the position, full-time parenthood would become a career option available for anyone, which would lead to the financial collapse of the state budget. If, by contrast, the position were made available only for parents who undertake 8 children, probably $6-8 \%$ of the population would be sufficient to deliver the expected results. However, having 8 children would excessively burden the participant families, therefore I suggest that the eligibility threshold be defined as having 5 children, with the system providing convincing incentives to encourage the participant families to have more than 5 children.

\section{How many full-time parents does society need?}

The answer to this question depends primarily on the population's average fertility rate and on the fertility rate achieved by full-time parents. For example, if the average fertility rate in a society is 1.3 and full-time parents have a statistical average of 5 children, the proportion of full-time women must be $21 \%$ to ensure the 2.1 rate. The following simple formula illustrates the scenario: 
790 women x 1.3 children/woman +210 women x 5 children/women $=1027+1050=2077$ children

In other words, 1000 women would have 2077 births - statistically speaking, one woman has 2.1 children. Columns 3, 5, and 7 in the table below illustrate the required ratio of full-time parents in a population with the average fertility rate ranging between 1.3 and 1.9 and the fertility rate of women employed as full-time parents varying between 4 and 6 .

Table 1. Calculation of the ratio of full-time parents

\begin{tabular}{|c|c|c|c|c|c|c|}
\hline $\begin{array}{c}\text { Fertility rate } \\
\text { of average } \\
\text { women }\end{array}$ & $\begin{array}{c}\text { Fertility rate } \\
\text { of full-time } \\
\text { mothers (F4) }\end{array}$ & $\begin{array}{c}\text { Rate of full- } \\
\text { time mothers } \\
\text { (R4) }\end{array}$ & F5 & R5 & F6 & R6 \\
\hline 1.3 & $\begin{array}{c}4 \text { children/ } \\
\text { women }\end{array}$ & $29 \%$ & 5 & $21 \%$ & 6 & $17 \%$ \\
\hline 1.5 & $\begin{array}{c}4 \text { children/ } \\
\text { women }\end{array}$ & $24 \%$ & 5 & $17 \%$ & 6 & $13 \%$ \\
\hline 1.7 & $\begin{array}{c}4 \text { children/ } \\
\text { women }\end{array}$ & $17 \%$ & 5 & $12 \%$ & 6 & $9 \%$ \\
\hline 1.9 & $\begin{array}{c}4 \text { children/ } \\
\text { women }\end{array}$ & $9 \%$ & 5 & $6 \%$ & 6 & $5 \%$ \\
\hline
\end{tabular}

As the table illustrates, if the spontaneous average fertility rate in a society's female population is 1.3 (first row, first column) and the fertility rate of fulltime mothers is 4 (second column), ideal fertility rates can be achieved if $29 \%$ of the population undertake full-time parenthood. If the spontaneous average fertility rate is 1.9 and the fertility rate of full-time mothers is 6 , ideal fertility rates can be achieved with only 5\% (last row, last column) of the population undertaking full-time parenthood. So, if the fertility rate of women who undertake full-time parenting reaches 6 , the ratio of full-time mothers can stay below $20 \%$ of the total female population in the fertile age bracket.

\section{Employment conditions}

Full-time parenthood, as the term shows, is not supposed to be available on a universal basis (not as a subjective right), but as a form of employment. Unlike the baby bonus, child benefit payments or tax reduction, full-time parenting would be a form of public employment, similar to the employment structure of professional foster parents, who also need to fulfil very strict eligibility conditions. Candidates for the job must be selected by the employer - in this case, the municipality, the state. As the duration of the employment ideally lasts until the employee reaches retirement age, the process of determining individual eligibility must be more thorough and more rigorous than usual. The peculiarities of reproductive work also require the employer to proceed with 
extraordinary caution.

The selection of full-time parents can have two pitfalls. The eligibility conditions determined by the employer might be so strict that only a small number of the applicants can qualify. The other possible issue is that women or couples who neglect their children might also be approved. As a result, these unschooled, poorly educated children might become adults unable to properly integrate into the world and subsequently worsen, rather than improve the real dependency ratio. The overall dependency ratio is the number of workers relative to all non-workers, including the elderly, the young, the disabled, and those choosing not to work [19]. The selection of full-time parents must, therefore, be carried out by navigating between the two risks as if navigating between Scylla and Charybdis. The risk of having negligent mothers in the system is more severe as it would have irreversible consequences, therefore all the parents approved for the position must be able to raise children who can become at least average taxpayers.

I suggest the application of the following selection criteria for prospective full-time parent couples: selected applicants must be married couples, their housing conditions must be at least average, they need to have completed at least secondary education and they must have a tax record that proves reliability. Let us examine these conditions:

(i) Marriage is known to be the most stable form of relationship. Rearing many children is obviously challenging for the couple, therefore married status is a justifiable selection criteria.

(ii) Living among at least average housing conditions is essential to guarantee that the living conditions of children to be born are by no means inferior to the conditions enjoyed by their peers.

(iii) The requirement of minimum average level of education is important because the statistical data available for Eastern Europe infer that a child's school achievements are largely influenced by the level of their parents' education. The higher the individual's level of education, the more likely they are to be useful members of society - being employed, being a disciplined taxpayer, rearing children.

(iv) A taxpayer record that is at least average is important because reliable taxpayers are more likely to raise taxpaying citizens. The institution of parenthood as full-time employment incurs high social expenses that can be significantly offset by the taxes to be later paid by the children raised in the participant families. It is, therefore, essential to have the highest possible proportion of taxpayers among the children raised in these families. If full-time parenthood created crowds of people unable to work, people who rely on welfare benefits, the institution would aggravate, rather than mitigate the demographic crisis. 


\section{Full-time parenthood as a career path}

The career of the full-time parent can be divided into the following phases: approval, the period of fertility, child rearing and child support, followed by retirement. The career of a full-time mother should ideally take the following path:

(i) She gets married at the age of 24, then the couple chooses the career of full-time parenthood for the woman and she is approved for the position.

(ii) In the fertile phase, the full-time mother gives birth to and rears 6 children. Obviously, during this period, only the woman is eligible for the position. Supposing that the woman gives birth to one child every 3 years on the average, the 6th child is born when the woman is 42 years old.

(iii) The educative period starts with the birth of the last child and it lasts, with gradually decreasing intensity, until the child becomes self-reliant. The first 12 years of this third phase, by the end of which the woman is 54 years of age, are more burdensome. During this period, the husband also becomes eligible for the position of full-time parent.

(iv) It would be unfair to send the older full-time parent back on the labour market at this age, therefore an indispensable income must be provided to the full-time parent (the mother or the husband). I suggest that the income should be calculated based on the tax revenues generated by grown-up offspring. Another aspect to consider is that by this phase, the couple's children will have become adults and if they have an average of 2 children of their own, the full-time parent will also participate in the raising of 12 grandchildren. If the full-time parents' own grandchildren live elsewhere, they can provide help to other full-time parents. The fulltime parent in the phase (iii) and (iv) has the option to work in other areas and earn additional money.

(vi) Finally, the full-time parent reaches retirement age and retires.

The implementation of the institution of full-time parenthood requires a very lengthy, approximately 40 years long commitment not only from the individual, but from society as well. At the same time, the individual is always free to decide whether to continue being employed within this framework or to look for a job as a breadwinner for a large family. Evidently, the state cannot terminate the employment of the full-time parent without providing justification for the decision, but the recruitment of new candidates can be halted. This aspect allows both the parents and the state to implement modifications and corrections. 
Social costs

The social costs of the institution of full-time parenthood are greatly influenced by the number of the full-time parents employed and their salary. The number of full-time parents, as previously discussed, would be $10-15 \%$ of the total female population in the fertile age bracket, that is, approximately equal with the number of primary school teachers, while their salary as public servants would equal the salary of a teacher employed in a kindergarten or in a primary school. The payment provided to full-time parents would increase fast, in parallel with the growing number of the children supported, reaching its peak when the woman is around the age of 42 and gradually decreasing afterwards.

When calculating social costs, the fact that a full-time mother can stay fertile for approximately 20 years must also be taken into consideration. This means that the number of full-time mothers in the system can be maintained stable only with an equal number of new entries. As a result, the costs of the process doubles after the first 20 years, but will not increase birth numbers. However, the number of full-time parents and the social costs of their employment will not increase further, because by the time "third-generation" full-time parents become employed, "first-generation" full-time parents retire.

During the first 15-20 years, the institution is going to be costlier, but after a while the system also starts generating revenue, as the children raised by fulltime parents become taxpayers. The economic benefits driven by the institution (more employees, more entrepreneurs and more taxpayers) will manifest only if the children raised by full-time parents do not lag behind their peers during childhood or in adulthood, as I have previously mentioned.

Here I note that society is becoming more open to expanding the interpretation of the concept of work, which is in line with the spirit of the present proposal. In the Eastern European and East-Asian countries struggling with the crisis of demographic winter, the extra resources should not be wasted on providing universal basic income - much rather, these resources should be spent on raising fertility rates, and within that, allocated for financing fulltime parenthood [20]. The advancement of Industry 4.0 is expected to release a substantial amount of industrial labour force, part of whom may consider full-time parenthood as a new career opportunity [21]. The way I see it, raising one's own children in Europe, or at least in Eastern Europe, will become an increasingly important way to earn a living. Otherwise, by the end of the century, the population of these countries will either vanish, or, more likely, their population will be replaced as a result of mass migration. 


\section{The implementation of the institution of full-time parenthood}

The complete implementation of the institution of full-time parenthood obviously takes time. Let us calculate with the slow and cautious implementation of full-time parenthood and let us assume that $0.25 \%$ of the fertile-aged female population is provided full-time parental status annually. In an aging country with a population of 10 million and roughly 2 million women in fertile age, this means 5,000 full-time parenting positions. In this case, in 10 years' time, the number of available full-time parent positions will reach 50,000 and will generate a yearly increase of 17,000 in the number of infants born. In 20 years, the number of full-time parents will reach 100,000 and there will be 35,000 more new-borns. After this 20 -year period, birth numbers through the institution of full-time parenthood stop increasing, but social costs continue to grow, reaching peak levels after 40 years. Thereafter, the costs associated with full-time parenthood will no longer increase. This way, the implementation of the system would take 40 years to fully develop, with the continuous employment of 100,000 full-time parents in the fertile age bracket and the same number of full-time parents older than that ( $>45$ years), giving birth to and raising 35,000 children per year. The institution of full-time parenthood will provide 385,000 births during the first 20 years, after which 700,000 children will be born over each subsequent 20 -year period. The number of grandchildren, at a fertility rate of 2 , would be the same, that is, 385,000 or 770,000 , born to "average" families.

To conclude, the institution of full-time parenthood, complete with classical pro-natalist measures, could secure the fertility rate of 2.1 by 2035 and would thus be able to stop the decline and the aging of the population in Eastern European countries over the long term.

\section{Bibliography}

[1] United Nations, Department of Economic and Social Affairs, Population Division, "Figure 8: Population by Total Fertility (millions)", World Population Prospects, the 2010 Revision, 2011. http://web.archive.org/web/20121028012124/http:/esa.un.org/unpd/wp p/Analytical-Figures/htm/fig_8.htm. Accessed: August 18, 2017.

[2] A. Turner. "Is a Shrinking Population Always a Bad Thing?." Social Europe on 27 August 2014. https://www.socialeurope.eu/shrinking-populationalways-bad-thing. Accessed: August 18, 2017.

[3] J. I. Tóth, "Demográfiai válság és a fenntarthatósági etika" [Demographic crisis and sustainability ethics]. Valóság 4 (2015): 26-33.

[4] Population Reference Bureau, "2016 World Population Date Sheet", http://www.prb.org/Publications/Datasheets/2016/2016-worldpopulation-data-sheet.aspx. Accessed: August 18, 2017. 
[5] A. Sauvy. " 'Le faux problème' de la population mondiale." Population 4(3): 447-462. English translation: "Alfred Sauvy on the World Population Problem: A View in 1949." Population and Development Review 16(4) (1990): 759-774.

[6] N. Folbre. "The Underpopulation Bomb." Economix. February 11, 2013 6:00 AM, http://economix.blogs.nytimes.com/2013/02/11/theunderpopulation-bomb/. Accessed: August 18, 2017.

[7] K. Kelly. "2013 What 'Should' We be Worried about? The Underpopulation Bomb.” Edge 2013 https://edge.org/responsedetail/23722. Accessed: August 18, 2017.

[8] S. E. Smoot. "Demographic Winter the Decline of the Human Family." SRB Documentary film LLC, USA, min. 52, 2008. http://demographicwinter.com. Accessed: August 18, 2017.

[9] P. Demeny. "Population Policy." 294-313. In Demography, vol. II., ed. Z. Yi . EOLSS Publications, 2010.

[10] L. Mucenieks, the Head of the Organization of Large Families in Latvia, conference lecture, at the 11th World Congress of Families (WCF) in Budapest, on 28 May 2017.

[11] B. Kapitány. "Demográfiai fogalomtár" [Demographic concept]. Budapest: KSH Népességtudományi Kutatóintézet, 2015. http://demografia.hu/hu/tudastar/fogalomtar/38-teljes-termekenysegiaranyszam. Accessed: August 18, 2017.

[12] "Ha így folytatjuk, 2100-ra tíz magyarból négy marad" [If we continue like this, by 2100 only one Hungarian will remain out of ten]. HVG, 10 August 2015, http://hvg.hu/gazdasag/20150810_Ha_igy_folytatjuk_2100ra_lefelezodun k. Accessed: August 18, 2017.

[13] United Nations. "World Population Prospects 2017, Population Division" https://esa.un.org/unpd/wpp/Graphs/Probabilistic/POP/TOT/. Accessed: August 18, 2017.

[14] Prime Minister Viktor Orbán's opening speech at the $11^{\text {th }}$ World Congress of Families (WCF) in Budapest, miniszterelnok.hu, 25 May 2017, Budapest. http://www.miniszterelnok.hu/prime-minister-viktor-orbans-openingspeech-at-the-2nd-budapest-world-congress-of-families/Accessed: August 18, 2017.

[15] G. Kligman. "Political Demography: The Banning of Abortion in Ceaușescu's Romania." 234-255. In Conceiving the New World Order: The Global Politics of Reproduction, ed. Ginsburg, Faye D., Rapp, Rayna. Berkeley: University of California Press, 1995.

[16] A. Miettinen, A. Rotkirch, I. Szalma, A. Donno and M.L. Tanturri, "Increasing Childlessness in Europe: Time Trends and Country 
Differences." Väestöliiton Väestöntutkimuslaitoksen työpaperi 2014 Working paper 5: 1-55, https://vaestoliitto-fibin.directo.fi/@Bin/921a4002358c4b7a03e09df65759e25b/1501911037/a pplication/pdf/3746805/Working\%20paper\%205_Increasing\%20Childles sness\%20in\%20Europe_1.pdf. Accessed: August 18, 2017.

[17] Hungarian Statistical Office (KSH). Women Aged 15 and Older and the Number of Live-born Children.

http://www.ksh.hu/nepszamlalas/tablak_teruleti_00. Accessed: August 18, 2017.

[18] J. I. Tóth. "Javaslat a fóállású szülő intézményének a bevezetésére" [Proposal for the introduction of a full-time parent institution]. Valóság 59(12) (2016): 33-42.

[19] B. Caplan. "The Real Dependency Ratio." Library of Economics and Liberty. Permanent Link, January 25, 2008 http://econlog.econlib.org/archives/2008/01/the_real_depend.html Accessed: August 18, 2017.

[20] About Basic Income. Basic Income Earth Network (BIEN) https://web.archive.org/web/20080621140909/http://www.basicincome. org/bien/aboutbasicincome.html. Accessed: August 18, 2017.

[21] M. Hermann, T. Pentek, B. Otto. "Design Principles for Industry 4.0 Scenarios." At System Sciences (HICSS), 49th Hawaii International Conference on System Sciences, 2016. 